\title{
PENGUATAN KARAKTER ANAK DALAM KELUARGA DALAM SITUASI PANDEMI COVID-19
}

\author{
Lailati Nazula, Erni Munastiwi \\ Universitas Islam Negeri Sunan Kalijaga Yogyakarta Indonesia \\ E-mail: laila.nazula731@gmail.com
}

\begin{abstract}
Abstrak: Situasi pendemi Covid-19 mengharuskan orang untuk beraktivitas dari rumah termasuk proses pembelajaran. Pembelajaran dari rumah menjadi peluang besar bagi keluarga untuk memanfaatkan situasi ini sebagai sarana penguatan karakter anak. Penguatan karakter atau disebut juga pendidikan karakter merupakan hal yang sangat penting agar mencetak manusia yang terpuji, baik untuk dirinya maupun lingkungannya. Penelitian ini bertujuan untuk mengeksplorasi pemanfaatan situasi pandemi sebagai sarana penguatan karakter anak yang dilakukan oleh orang tua. Dengan metode kualitatif, melalui pendekatan grounded theory penelitian ini mengikutsertakan tiga partisipan yang dipilih secara acak (random sampling). Data dalam penelitian dikumpulkan melalui wawancara dengan menggunkakan pertanyaan terbuka. Sebelum dilakukan analisis data, terlebih dahulu dilakukan pengecekan keabsahan data menggunakan teknik member checking, yang dilanjutkan dengan analisis menggunakan teknik coding. Dari penelitian yang dilakukan ditemukan hasil bahwa situasi pandemi ini dapat menjadi sarana penguatan karakter anak. Hal ini dilakukan orang tua dengan cara menciptakan nilai mandiri, tanggung jawab, religius, gotong-royong, dan nasionalis menjadi momentum bagi keluarga untuk terlibat dalam pendidikan karakter dan membangun harmonisasi dengan anak, menjadikan anak belajar pola hidup bersih dan sehat, dan anak berkurang dari aktivitas lingkungan luar yang kurang bermanfaat.
\end{abstract}

Kata kunci: penguatan karakter, covid-19, pandemi, keluarga, pendidikan karakter

\section{STRENGTHENING CHILDREN'S CHARACTER IN THE FAMILY IN THE COVID-19 PANDEMIC SITUATION}

\begin{abstract}
The Covid-19 pandemic situation requires people to be active from home, including the learning process. Learning from home is a great opportunity for families to take advantage of this situation as a means of strengthening children's characters. Strengthening character or also called character education is very important in order to produce commendable human beings, both for themselves and their environment. This study aims to explore the use of the pandemic situation as a means of strengthening children's characters by parents. With a qualitative method, through a grounded theory approach, this study included three participants who were selected at random (random sampling). The data were collected through interviews using open-ended questions. Prior to data analysis, the validity of the data was checked using the member checking technique, followed by analysis using coding techniques. From the research conducted, it was found that this pandemic situation can be a means of strengthening children's characters. This is done by parents by creating independent, responsible, religious, mutual cooperation, and nationalist values to become a momentum for families to be involved in character education and build harmonization with children, made children learn clean and healthy lifestyles, and reduced from activities outside the environment that are less useful.
\end{abstract}

Keywords: strengthening character, covid-19, pandemic, family, character education

\section{PENDAHULUAN}

Penyebaran pandemi Covid-19 menjadi situasi yang sepesial khususnya dalam penerapan sistem pembelajaran anak. Pasalnya, saat ini semua orang diharapkan untuk melakukan aktivitas di rumah dan tidak melakukan perjalanan yang tidak diperlukan, termasuk kegiatan belajar-mengajar (Yazid \& Lie, 2020, p. 78). Covid-19 atau disebut juga dengan Corona Virus Disease, menjadi sebab keluarnya Surat Edaran Menteri Pendidikan dan Kebuda- 
yaan Nomor 4 Tahun 2020 tentang Pelaksanaan Pendidikan dalam Masa Darurat Covid-19. Surat edaran ini berisi beberapa aturan yang harus diikuti dalam dunia pendidikan aturan ini berbicara tentang ujian nasional, proses pembelajaran yang dilakukan dari rumah, ujian sekolah, penerimaan peserta didk baru, kenaikan kelas siswa dan bantuan opersional sekolah (Subarto, 2020, p. 14). Pembelajaran melalui daring tentu saja jika diteliti akan ditemukan beberapa kekurangan di dalamnya. Salah satu kelemahan pembelajran daring yang dikemukakan oleh Firman dan Rahayu (2020, p. 86) bahwa pembelajaran online menyulitkan guru atau pendidik untuk memeriksa sikap peserta didik, bahkan komunikasi antara guru/pendidik dan siswa sangat terbatas. Walaupun pembelajaran ini juga tidak sepenuhnya memberikan dampak negatif, namun juga dinilai dapat memebrikan beberapa manfaat, di antaranya dapat menjadikan siswa lebih aktif dan melatih kemandirian belajar (Firman \& Rahayu, 2020, p. 86) atau selfregulating learning (Subarto, 2020, p. 13). Menurut observasi singkat peneliti, siatuasi pandemi memberikan kesempatan kepada orang tua untuk ikut terjun banyak dalam proses pendidikan anak dari pada sebelumnya yang ini menjadi kesempatan untuk menguatkan karakter anak.

Penguatan karakter berarti juga pendidikan yang diberikan untuk menguatkan pribadi siswa sehingga terbentuk anak yang berkarakter (Arofah, 2017, p. 119). Pendidikan karakter sendiri merupakan sesuatu yang sangat dibutuh setiap individu. Menurut Maksudin (2015, p. 66) hakikat pendidikan karakter merupakan bagian dari semua pendidikan yang ada, karena melalui pendidikan karakter, seseorang dapat memperbaiki hal yang bersifat lahiriyah dan batiniah agar menjadi manusia yang lebih baik untuk dirinya dan lingkungannya. Pendidikan karakter diartikan sebagai sistem penerapan nilai moral melalui pengetahuan kesadaran atau kemauan dan implementasinya kepada siswa, baik untuk dirinya sendiri, orang lain, lingkungan, bangsa, dan juga Tuhannya (Wulandari \& Kristiawan, 2017, p. 291). Penguatan karakter anak sangat penting karena akan memberikan dampak positif bagi kehidupan mental dan spiritual anak (Ariyati \& Dimyati, 2018, p. 158).

Pertanyaan selanjutnya yaitu dari manakah pendidikan karakter ini harus dimulai? Menurut Hanafi (2017, p. 140) penerapan nilai dapat dilakukan dengan diadakannya penanaman nilai kepada seseorang sejak dini, mulai dari keluarga, masyarakat, dan juga lembaga pendidikan. Hal ini sejalan dengan penjelasan Dahliyana (2017, p. 55) bahwa secara kecil, pendidikan karakter terdiri atas empat pokok, yaitu kegiatan dalam kelas, kegiatan kokurikuler dan ekstrakurikuler, kegiatan harian baik yang bersifat formal maupun di luar itu, juga kegiatan harian di rumah dan sosial masyarakat. Tiga pilar yang sering disebutkan memiliki tanggung jawab dalam mendidik anak yaitu keluarga, sekolah, dan masyarakat. Setiap pilar memiliki peran yang tidak dapat dipisahkan, namun keluarga memiliki tanggung jawab yang utama dan pertama (Ariyati \& Dimyati, 2018, p. 152). Berbeda dengan pernyataan Komara (2018, p. 18) bahwa sekolahlah yang berperan lebih besar dalam pendidikan anak karena sekolah merupakan kelompok masyarakat yang dapat disetting untuk membentuk karakter siswa di dalamnya disebut juga dengan communities of character. Terdapat lima nilai karakter yang menjadi nilai-nilai yang harus diprioritaskan untuk ditanamkan kepada siswa oleh Kementrian Pendidikan dan Kebudayaan 
Republik Indonesia tahun 2017. Lima nilai karakter tersebut yaitu nilai religius, nilai mandiri, nasionalis, gotong-royong, dan integritas (Komara, 2018, p. 18).

Dari pemaparan tersebut diketahui bahwa keluarga menjadi hal sentral dalam pendidikan kerakter terutama di masa pandemi ini, dikarenakan proses pembelajaran yang diadakan oleh sekolah hanya bisa dilakukan melalui media online atau daring. Seperti yang dikemukakakn oleh Subarto (2020, p. 13) bahwa selama masa pandemi, peran yang biasa dilakukan oleh satuan pendidikan kini berpindah ke peran satuan keluarga. Salah satu anggota dalam keluarga, yaitu orang tua. Orang tua dalam keluarga memiliki banyak peran dan pengaruh dalam kesuksesan pendidikan karakter (Wulandari \& Kristiawan, 2017, p. 294). Paling tidak ada tiga peran orang tua dalam pendidikan karakter anak, yaitu membuat anak merasa aman dan nyaman, menjadi teladan yang baik bagi anak, dan mendisiplinkan anak untuk bersikap baik sesuai dengan pengetahuan yang telah diberikan (Akhyadi \& Mulyono, 2019, p. 4).

Penguatan karakter anak juga membutuhkan strategi yang tepat untuk dilakukan. Strategi pembentukan karakter ditempuh melalui strategi holistif-integratif yang mengandung lima rukun strategi yakni (1) moral acting melalui habituasi dan pembudayaan, atau membiasakan anak dengan hal terterntu yang ingin ditanamkan sehingga hal tersebut dapat menjadi hal yang dipikirkan, diyakini, dan diinginkan anak; (2) moral knowing, atau membelajarkan pengetahuan tentang nilai-nilai yang baik, karena pembiasaan saja tidak cukup, namun harus dibarengi dengan pemahaman dan pengetahuan tentang tindakan mana yang baik dan buruk; (3) moral feeling and loving, atau melatih anak untuk dapat merasakan yang baik dan juga mencintai yang baik pula; (4) moral model, atau memberikan contoh yang baik bagi anak di lingkungan yang dilihat karena hal itu akan lebih mudah ditiru; dan yang terakhir (5) tobat dari dosa dan perilaku yang tidak bermanfaat melalui tiga rukun yakni takhalli, tahalli, dan tajalli (Maragustam, 2018, p. 285-88). Menurut Lickona $(1991 ; 2004)$ pendidikan karakter ditempuh melalui (1) moral knowing, (2) moral feeling, dan (3) moral action.

Belum ditemukan sebelumnya penelitian yang mengangkat tema pemanfaatan situasi pandemi Covid-19 sebagai sarana penguatan karakter anak seperi ini. Namun ada beberapa penelitian yang terkait dengan tema penelitian seperti ini. Untuk mengetahui posisi penelitian ini, dilakukan sebuah pencarian terhadap penelitian-penelitian yang telah dilakukan oleh beberapa peneliti lain.

Dari hasil pencarian akan dijelaskan dua penelitian saja. Pertama, penelitian yang dilakukan oleh Subarto (2020). Walaupun tidak membahas secara langsung tentang pendidikan karakter di tengah pandemi, Subarto (2020) meneliti tentang momentum keluarga mengembangkan kemampuan belajar peserta didik di tengah pandemi. Subarto (2020) menjelasakan bagaimana peran orang tua yang sangat penting dalam mengembangkan sikap selfregulating learning kepada anak di tengah pandemic. Keluarga adalah komunitas pertama yang dimiliki oleh individu. Di situasi pandemi, peran yang biasa dilakukan oleh satuan pendidikan kini berpindah ke peran satuan keluarga. Perilaku yang dilakukan oleh keluarga anak tentu akan memberikan pengaruh terhadap cara berperilaku anak. Selain itu, penelitian ini juga menjelaskan tentang strategi yang diambil orang tua dalam pendampingan belajar anak, yakni mendiskusikan aturan di dalam rumah, menunjukan perilaku yang dapat dicontoh, 
memecahkan masalah, menjadi sahabat dan teman, menunjukan strategi yang konkrit untuk mempertahankan kemampuan belajar, menunjukan cara belajar efektif, dan memberi kesempatan anak untuk mengerjakan tugas secara mandiri.

Kedua, penelitian tentang penguatan karakter anak yang dilakukan oleh beberapa peneliti (Ariyati \& Dimyati 2018; Arofah, 2017; Dahliyana, 2017; dan Wulandari \& Kristiawan, 2017). Setiap dari penelitian ini menghubungkan pengutaan karakter dengan beberapa hal yang berbeda. Penguatan karakter ini salah satunya dapat dilakukan dengan penjawatahan pengetahuan di kelas tentang sikap dan keterampilan yang harus dikembangkan dalam bentuk nilai-nilai yang harus ditanamkan agar dapat dimiliki siswa (Dahliyana, 2017). Untuk menguatkan karakter anak, sekolah harus dapat memaksimalkan peran orang tua dalam upaya penguatan karakter siswa. Penguatan pendidikan karakter di sekolah dapat dilakukan melalui: pengangkatan nilai dalam visi, membangun hubungan yang kuat, menyiapkan pendidikan yang baik, dan menyiapkan lingkungan sekolah yang aman, nyaman dan menstimulasi pendidikan karakter (Wulandari \& Kristiawan, 2017). Arofah (2017) menemukan bahwa self-disiplin merupakan hal penting dalam penguatan karakter. Sementara itu, Ariyati dan Dimyati (2018) menegaskan bahwa keluargalah yang berperan cukup besar dalam penguatan karakter anak terutama pada anak usia dini.

\section{METODE}

Penelitian ini menggunakan metode kualitatif dengan pendekatan grounded theory. Pendekatan ini dipilih karena dinilai menjadi pendekatan yang paling tepat untuk digunakan pada penelitian. Pendekatan Grounded Theory Method (GTM) merupa- kan metodologi umum untuk membangun teori yang didasarkan pada data yang dikumpulkan dan dianalisis secara sistematis (Bryant, 2017). Partisipan dalam penelitian tentu disesuaikan dengan tujuan penelitian yaitu orang tua (yang memiliki anak). Penelitian ini melibatkan tiga orang tua yang diambil dari sebuah desa di Kecamatan Rowosari Kabupaten Kendal yang merupakan daerah pedesaan semi kota. Sesuai yang dikatakan oleh Cohen, Manion, \& Marrison (2011, p. 75), bahwa dalam penelitian kualitatif tidak ada atauran khusus pada jumlah partisipan yang terlibat pada penelitian.

Pengumpulan data dalam penelitian ini dilakukan dengan pengambilan partisipan secara random. Dalam cara ini tidak ada kriteria khusus yang harus dipenuhi oleh partisipan. Partisipan dalam penelitian ini mendapatkan empat pertanyaan yang sama, yaitu tentang (1) urgensi pendidikan karakter di tengah pandemi covid19; (2) kegiatan yang dilakukan untuk menguatkan karakter di tengah pandemi; (3) strategi yang dilakukan untuk menuatkan karakter di tengah pandemi, dan (4) pemanfaatan atau keuntungan yang didapat dari situasi pandemi sebagai sarana menguatkan karakter anak.

Untuk memastikan bahwa data yang didapat merupakan data asli (data yang didapat dari partisipan), dilakukan validitas data dengan menggunakan teknik member-checking. Data yang telah didapat dianalis menggunakan teknik coding yang meliputi beberapa tahap. Tahap pertama yaitu open coding, yang dilakukan dengan memberikan lebel pada data yang sesuai dengan penelitian. Tahap kedua yaitu analytical coding atau memberikan tema pada setiap data yang didapat pada open coding. Tahap ketiga yaitu axial coding yang dilakukan dengan mengategorisasikan tema- 
tema yang memiliki kesamaan ide. Yang terakhir yaitu selective coding, sesuai dengan namanya di sini, peneliti memilih ataupun menentukan kategori inti dari data yang akan dijelaskan dalam teori terkait (Budiasih, 2013).

\section{HASIL DAN PEMBAHASAN}

Setelah dilakukan analisis terhadap data yang telah didapat, ditemukan beberapa poin dalam penelitian penguatan karakter anak dalam situasi pendemi Covid-19. Hasil dari wawancara dengan para partisipan terkait dengan penguatan karakter anak dapat dilihat pada Tabel 1.

Tabel 1. Hasil Wawancara dengan Partisipan

\begin{tabular}{|c|c|c|c|}
\hline $\begin{array}{l}\text { Urgensi Pendidik- } \\
\text { an Karakter di } \\
\text { Tengah Pandemi }\end{array}$ & $\begin{array}{l}\text { Kegiatan yang } \\
\text { Dilakukan }\end{array}$ & $\begin{array}{l}\text { Strategi yang } \\
\text { Diterapkan }\end{array}$ & $\begin{array}{c}\text { Manfaat atau Keuntungan yang } \\
\text { bisa Dilakukan/Didapatkan }\end{array}$ \\
\hline $\begin{array}{l}\text { 1. Pendidikan karak- } \\
\text { ter membantu pe- } \\
\text { nyelesaian } \\
\text { pandemi. } \\
\text { 2. Kontinuitas pendi- } \\
\text { dikan karakter ha- } \\
\text { rus tetap diperta- } \\
\text { hankan walau di } \\
\text { tengah pandemi. }\end{array}$ & $\begin{array}{l}\text { 1. Membangun ke- } \\
\text { giatan sesuai de- } \\
\text { ngan nilai yang } \\
\text { akan dibangun. } \\
\text { 2. Melaksanakan } \\
\text { kegiatan sekolah } \\
\text { di rumah. }\end{array}$ & $\begin{array}{l}\text { 1. Pembelajaran, } \\
\text { pembiasaan, pe- } \\
\text { nguatan, dan ke- } \\
\text { teladanan. } \\
\text { 2. Penguatan ko- } \\
\text { munikasi }\end{array}$ & $\begin{array}{l}\text { 1. Menciptakan nilai mandiri, } \\
\text { tanggung jawab, dan kolaborasi. } \\
\text { 2. Memaksa orang tua untuk ter- } \\
\text { libat lebih besar dalam pen- } \\
\text { didikan karakter anak dengan } \\
\text { cara bekerja sama dengan guru. } \\
\text { 3. Memberikan kesempatan pada } \\
\text { orang tua untuk mengawasi } \\
\text { anak dengan kebersamaan yang } \\
\text { dimiliki. } \\
\text { 4. Anak semakin erat dan harmo- } \\
\text { nis dengan keluarga. } \\
\text { 5. Anak beribadah dengan baik } \\
\text { dan teratur. } \\
\text { 6. Anak belajar pola hidup bersih } \\
\text { dan sehat, anak berkurang dari } \\
\text { aktivitas lingkungan luar yang } \\
\text { kurang bermanfaat. }\end{array}$ \\
\hline
\end{tabular}

Dari hasil yang didapatkan seperti dipaparkan pada tabel 1 di atas berikutnya diuraikan mengenai alasan, kegiatan, cara dan manfaat yang didapatkan oleh orang tua anak di tengah situasi pendemi Covid19 secara mendalam.

\section{Urgensi Pendidikan Karakter di Tengah Pandemi Covid-19}

Sebelum membahas lebih lanjut tentang pemanfaatan situasi pandemi sebagai sarana penguatan karakter anak, lebih dahulu diungkap kesadaran tentang pentingnya pendidikan karakter. Walaupun memiliki alasan yang bebeda-beda, ketiga partisipan mengakui bahwa pendidikan karakter di tengah pandemi sangat dibutuhkan.
Pendidikan karakter dinilai mampu untuk membantu menciptakan rakyat yang lebih patuh dengan aturan terkait dengan pandemi. Hal ini sejalan dengan pernyataan Budiman \& Suva (2018, p. 135) bahwa pendidikan karakter sangat dibutuhkan oleh setiap individu untuk menjadikannya taat terhadap aturan atau norma sekitar. Salah satu norma yang dimaksud di sini adalah prosedur atau langkah pencegahan penyebaran virus ini, termasuk menjauhkan diri dari wabah, memohon perlindungan Allah, mencuci tangan setiap waktu, mengenakan masker, makan makanan yang bersih, sehat, bergizi halal, dan tetap bersikap optimis (Arifin, et al., 2020, p. 12). Tidak dapat dipungkiri bahwa prosedur keselamatan 
dalam masa pandemi ini sangat membutuhkan dasar sikap yang baik, yang bisa berupa empati, disiplin, dan patuh. Kesadran akan kebaikan dan keburukan baik untuk diri sendiri maupun untuk luar diri sendiri sangat dibutuhkan di masa yang seperti ini. Pendidikan karakter akan memunculkan hati nurani moral yang akan memberikan motifasi kepada manusia untuk selalu berbuat kebaikan dan menghindari perbuatan yang tidak baik (Maragustam, 2015, p. 268). Berbeda dengan pendapat sebelumnya, partisipan ketiga menyatakan bahwa pendidikan karakter memang sejatinya sangat penting, baik sebelum maupun sesudah masa pandemi. Untuk itu, yang awalnya pendidikan karakter anak ini bersandar besar kepada guru dan sekolah, maka di masa pandemi ini keluarga atau orang tualah yang dianggap harus mengambil alih tanggung jawab besar ini. Ia juga menegaskan bahwa sekolah dan guru harus tetap ikut andil walaupun dengan keterbatasan sarana, dikarenakan proses pembelajaran dilakukan secara online. Hal ini sejalan dengan apa yang dinyatakan Munastiwi (2015, p. 89) bahwa pendidikan karakter dimulai dari awal hingga akhir. Dengan artian bahwa proses dalam pendidikan karakter tidak boleh dihentikan dan harus terus berlangsung.

\section{Strategi yang Dilakukan untuk Menguat- kan Karakter di Tengah Pandemi}

Membicarakan pendidikan dan penguatan karakter tentu tidak luput dari strategi yang diterapkan untuk melaksanakannya. Dalam penelitian ini, peneliti menemukan dua pendapat yang dinilai dapat dilakukan untuk menguatkan karakter anak. Yang pertama yaitu penerapan konsep pembelajaran, pembiasaan, penguatan dan keteladanan. Strategi yang seperti ini sebenarnya telah banyak diungkapkan oleh beberapa ahli di antaranya Maragustam (2018) yang menjelaskan strategi pembentukan karakter dengan holistik-integratif, yang dijelaskan dengan lima bagian strategi yaitu moral acting, moral knowing, moral feeling and loving, moral model, dan tobat dari dosa dan perilaku yang tidak bermanfaat melalui takhalli (penarikan diri atau manarik diri dari segala yang mengalihkan dirinya dari kebaikan dengan penuh penyesalan), tahalli (berhias dengan perilaku terpuji atau mencoba menyibukkan diri dengan perbuatan dan sikap baik), dan tajalli (berupa hidayah yang memperlihatkan kebenaran yang ditunjukan oleh cahaya ghaib, sebagai hasil dari unsur takhalli dan tahalii).

Dalam penerapannya, partisipan menjelaskan lebih rinci tentang keteladanan yang pada masa pandemi ini keteladanan difokuskan kepada orang tua. Yang menjadi figurnya bukan lagi guru, karena di masa pandemi ini anak akan sangat jarang bertemu guru. Untuk itu, dalam hal ini ia menegaskan bahwa orang tua harus mampu untuk bersikap baik agar menjadi teladan yang baik bagi anak. Berbeda dengan partisipan yang lain yang menyatakan bahwa strategi yang dilakukan yaitu menjalin komunikasi yang baik dengan anak dan juga guru melalui medsos.

Pendalaman komunikasi kepada anak memang sangat dibutuhkan terutama untuk memahami sifat dan sikap anak. Orang tua ataupun keluarga merupakan kelompok pertama yang memberikan pengaruh kepada anak (Subarto, 2020). Namun, komunikasi terhadap guru juga harus tetap berjalan, karena harus disadari bahwa pendidikan merupakan tanggung jawab bersama baik pemerintah, sekolah (guru), maupun keluarga (orang tua). 
Kegiatan yang Dilakukan untuk Menguatkan Karakter di Tengah Pandemi

Berkaitan dengan strategi yang diterapkan, tentunya ada beberapa kegiatan yang dilaksanakan guna untuk memperkuat karakter anak di tengah masa pandemi ini. Dari data yang diperoleh dari partisipan, dapat dijelaskan di sini beberapa kegiatan yang dilakukan untuk menguatkan karakter di masa pandemi ini.

1. Melakukan kegiatan sesuai dengan nilai yang akan dibangun, seperti: ibadah untuk menumbuhkan nilai religiusitas, melaksanakan tugas rumah dan sekolah untuk menumbuhkan nilai mandiri dan tanggung jawab, bekerja sama mengerjakan tugas dengan anggota keluarga untuk menumbuhkan nilai gotong-royong, dan taat aturan pemerintah sebgai wujud nilai nasionalis.

2. Melaksanakan kegiatan sekolah atau kegiatan yang seharusnya dilakukan di sekolah dan di rumah, seperti salat, membaca Alquran, dll.

3. Melaksanakan tugas yang diberikan sekolah.

4. Menjaga hidup bersih dan sehat serta mengikuti himbauan pemerintah.

Nilai yang diungkapkan oleh partisipan pertama sudah sesuai dengan lima nilai utama yang diprioritaskan oleh pemerintah dalam program penguatan pendidikan karakter (PPK) seperti yang telah disebutkan juga oleh Komara (2018, p. 18).

\section{Pemanfaatan dari Situasi Pandemi se-} bagai Sarana Menguatkan Karakter Anak

Situasi pandemi yang dialami saat ini tentu saja bukan situasi yang menyenangkan bahkan dapat dikatakan bahwa situasi ini merupakan situasi yang mengarah pada krisis. Akan tetapi, tidak mungkin ada sesuatu hal yang datang pada diri manusia tanpa mengandung kebaikan dan keburuk- an. Untuk itu perlu digali tentang kebaikan ataupun manfaat yang dapat diambil dari situasi ini, terutama dalam hal penguatan pendidikan karakter bagi anak. Dari penelitian ini ditemukan beberapa hal penting sebagai berikut.

1. Menciptakan nilai mandiri, tanggung jawab, religius, gotong-royong, dan nasionalis.

2. Momentum bagi keluarga untuk terlibat dalam pendidikan karakter dan membangun harmonisasi dengan anak.

3. Anak belajar tentang pola hidup bersih dan sehat.

4. Anak mengurangi aktivitas lingkungan luar yang kurang bermanfaat.

Nilai-nilai yang diungkapkan pada poin pertama, merupakan nilai yang diidentifikasi oleh kementrian agama menjadi nilai utama yang harus ditanamkan kepada setiap individu seperti yang telah disebutkan sebelumnya. Nilai mandiri sendiri didefinisikan sebagai sikap untuk lebih bisa mengandalkan diri sendiri dan tidak mudah bergantung pada orang lain dalam bersikap tanggung jawab (Purwaningsih). Sikap mandiri ini dapat dikembangkan oleh individu dalam keluarga. Hal ini dikarenakan keluarga merupakan kelompok pertama yang dimiliki seseorang yang mengharuskannya untuk mencoba menjadikan dirinya sebagai seorang anggota, bukan individu semata. Dengan proses inilah individu dapat berkembang menjadi individu yang mandiri (Najib \& Achadiyah, 2012, p. 102). Untuk itu nilai ini sangat tepat dikembangkan di masa pandemi seperti saat ini. Anak dapat menghabiskan waktunya di rumah bersama dengan keluarga. Nilai mandiri terbukti dapat mengantarkan anak didik kepada meraih prestasi belajar yang baik, karena pendidikan karakter mandiri yang ditanamkan kepada anak didik membuat mereka 
memiliki karakter manidri dan tidak bergantung kepada guru dalam pembelajaran, sehingga mampu untuk mengantarkannya untuk mendapatkan prestasi yang baik (Budiyanto \& Machali, 2014, p. 108). Nilai religiusitas atau disebut juga spiritualitas dianggap penting karena untuk mewujudkan peserta didik yang bernilai dan berkarakter perlu ditanamkannya nilai spiritual keagamaan (ma'rifatullah) yang berintikan tauhid. Penanaman nilai spiritual keagamaan ini tidak lain untuk menjadikan anak didik mampu memberikan makna terhadap kehidupannya dan hakikat hidupnya (Hanafi, 2017, p. 142). Mengetahui Tuhannya, akan menjadikan seseorang dapat menghubungan apa yang dimiliki kepada Allah (secara transendental), seperti pola pikir, pola rasa, dan pola hati (Maragustam, 2015, p. 286). Nilai ini dapat dibangun dengan kegiatan-kegiatan ibadah di rumah yang dilakukan bersama antara orang tua dan anak seperti yang telah dijalankan oleh partisipan di masa ini.

Nilai yang terakhir yang dapat dibangun di momen pandemi ini yaitu nilai nasionalis. Seperti yang diungkapkan oleh partisipan ketiga bahwa pada masa pandemi ini orang tua memiliki kesempatan untuk mendidik anak menaati peraturan pemerintah khususnya berkaitan dengan penyebaran wabah di negara ini. Seperti yang dijelaskan Shabrina (2020) di tengah pandemi ini dapat diperkuat kesadaran bela negara atau upaya untuk mempertahankan negara dari hal yang mengganggu keberlangsungan hidup rakyat Indonesia yang berlandaskan kecintaan pada tanah air. Pada masa pandemi ini bela negara dapat diwujudkan dalam bentuk menjaga kebersihan seperti yang disebutkan pada poin 3, yakni menjaga imunitas tubuh agar tetap stabil, selalu mencuci tangan, dan makan makanan sehat.
Seperti yang telah disebutkan bahwa masa pandemi menjadikan masayarakat melakukan aktivitas dari rumah. Hal ini menjadikan anggota keluarga memiliki waktu yang lebih besar untuk bersama. Seperti yang diungkapkan oleh Maragustam (2018) bahwa salah satu strategi yang dilakukan untuk memperkuat karakter anak yaitu dengan adanya moral modeling (keteladanan) yang memaksa orang tua untuk menjadi pusat dari perhatian anak di masa pandemi ini sehingga orang tua berperan besar dalam hal ini. Maragustam (2018)) juga mengungkapkan bahwa ketika merujuk pada dua aliran karakter (positif aktif dan dualis aktif), karakter manusia tidak sepenuhnya didapat dari lahir, namun karakter ini juga didapat dari faktor lingkungan yang mempengaruhi anak. Untuk itu, lingkungan yang baik akan menjadi potensi bagi anak untuk menjadi baik pula, di masa pandemi inilah saat anak terbebas dari lingkungan luar dan kekuasaan penciptaan lingkungan ada di tangan keluarga (orang tua).

Secara garis besar pemanfaatan situasi pandemi covid19 sebagai penguatan karakter dalam keluarga dapat dilihat pada Gambar 1.

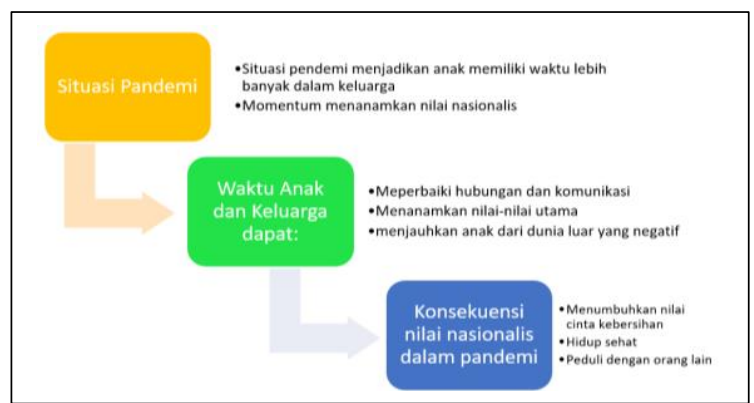

Gambar 1. Pemanfaatan Situasi Pandemi Covid19 dalam Penguatan Karakter Anak dalam Keluarga

\section{SIMPULAN}

Pendidikan karakter merupakan hal penting bagi kehidupan manusia termasuk pada saat pandemi Covid-19 ini. Pendidik- 
an karakter dinilai mampu membantu mengedukasi masyarakat untuk mencegah penyebaran wabah. Meskipun starategi yang diterapkan tidak jauh berbeda dengan pendidikan karakter pada umumnya, pada masa pandemi orang tua memiliki kesempatan untuk melakukan berbagai aktivitas sepert melakukan kegiatan sesuai dengan nilai karakter yang akan dikembangkan. Misalnya: ibadah untuk menumbuhkan nilai religiusitas, melaksanakan tugas rumah dan sekolah untuk menumbuhkan nilai mandiri dan tanggung jawab, bekerja sama mengerjakan tugas dengan anggota keluarga untuk menumbuhkan nilai gotong royong, dan taat aturan pemerintah sebgai wujud nilai nasionalis, melaksanakan kegiatan sekolah atau kegiatan yang seharusnya dilakukan di sekolah dan di rumah, melaksanakan tugas yang diberikan sekolah, menjaga hidup bersih dan sehat, serta mengikuti himbauan pemerintah. Kegiatan-kegiatan ini dapat dimanfaatkan untuk menciptakan nilai mandiri, tanggung jawab, religius, gotong-royong dan nasionalis, serta menjadi momentum bagi keluarga untuk terlibat dalam pendidikan karakter dan membangun harmonisasi dengan anak, mengajarkan anak belajar pola hidup bersih dan sehat, dan mengurangi anak dari aktivitas di lingkungan luar keluarga yang kurang bermanfaat.

\section{UCAPAN TERIMA KASIH}

Ucapan terima kasih disampaikan kepada semua pihak yang telah membantu proses penelitian ini selesainya penulisan artikel ini. Ucapan terima kasih secara khusus juga disampaikan kepada ibu-ibu yang telah berpartisipasi pada penelitian ini.

\section{DAFTAR PUSTAKA}

Akhyadi, A.S. \& Mulyono, D. (2019). Program parenting dalam meningkatkan kualitas pendidikan keluarga. Abdimas Siliwangi, 1(1), 1-8. DOI: http://dx.doi.org/10.22460/as.v1i1p1-8.34.

Arifin, T., Nuraeni, N., Mashudi, D., \& Saefudin, E. (2020). Proteksi diri saat pandemi Covid-19 berdasarkan hadits shahih, 1-15. Retrieved from https://core.ac.uk/download/pdf/3 27164615.pdf.

Ariyati, T. \& Dimyati, D. (2018). Pentingnya peran keluarga untuk penguatan karakter dalam membentuk akhlak baik pada anak usia dini. Dalam $S e$ minar Nasional dan Call for Paper "Membangun Sinergitas Keluarga dan Sekolah Menuju PAUD Berkualitas" (152-158). Retrieved from http://eprints.uad.ac.id/id/eprint/13547.

Arofah, L. (2017). Pentingnya siswa memiliki self discipline sebagai alternatif penguatan karakter. Dalam Seminar Nasional Bimbingan Konseling Universitas Ahmad Dahlan, 2, 117-122. Retrieved from http://seminar.uad.ac.id/index.php/snbkuad/article/view /67/71.

Bryant, A. (2017). Grounded theory and grounded theorizing; pragmatism in research practice. New York: Oxford Universsity Press.

Budiasih, I.G.A.N. (2013). Metode grounded theory dalam riset kualitatif. Jurnal Ilmiah Akuntansi Dan Bisnis, 9(1), 19-27.

Budiman, A. \& Suva, P.R. (2018). Urgensi pembentukan karakter anak di era 
globalisasi melalui penguatan keluarga. Aplikasia: Jurnal Aplikasi Ilmuilmu Agama, 18(2), 135-142. DOI:https://doi.org/10.14421/aplikasia. v18i2.1846.

Budiyanto, M. \& Machali, I. (2014). Pembentukan karakter mandiri melalui pendidikan agriculture di Pondok Pesantren Islamic Studies Center Aswaja Lintang Songo Piyungan Bantul Yogyakarta. Jurnal Pendidikan Karakter, 4(2), 108-122. DOI: https://doi.org/10.21831/jpk.v0i2.2784.

Cohen, L. (2011). Observation. In Cohen, L., Manion, L. \& Morrison, K. (Eds.). Research Methods in Education 7.

Dahliyana, A. (2017). Penguatan pendidikan karakter melalui kegiatan ekstrakurikuler di sekolah. Sosio Religi: Jurnal Kajian Pendidikan Umum, 15(1), 5464. Retrieved from https://ejournal.upi.edu/index.php/SosioReligi/artic le/view/5628.

Firman, F. \& Rahayu, S. (2020). Pembelajaran online di tengah pandemi Covid19. Indonesian Journal of Educational Science (IJES), 2(2):81-89. DOI: https: // doi.org/10.31605/ijes.v2i2.659.

Hanafi, I. (2017). Urgensi penanaman nilai karakter spiritual keagamaan dan integritas dalam dunia pendidikan. AnNuha: Jurnal Kajian Islam, Pendidikan, Budaya \& Sosial, 4(2), 139-151. Retrieved from http://ejournal.staimadiun.ac.id/index.php/annuha/articl e/view/171.

Komara, E. (2018). Penguatan pendidikan karakter dan pembelajaran abad 21. SIPATAHOENAN, 4(1), 17-26. DOI: https:/doi.org/10.2121/sip.v4i1.991.
Lickona, T. (1991). Educating for character: how our school can teach respect and responsibility. New York, Toronto, London, Sydney, Aucland: Bantam books.

Lickona, T. (2004). Character matters: How to help our children develop good judgment, integrity, and other essential virtues. New York, London, Toronto, Sidney: Simon \& Schuster.

Maksudin. (2015). Desain pengembangan berpikir integratif interkonektif pendekatan dialektik. Yogyakarta: Pustaka Pelajar.

Maragustam. (2018). Filsafat pendidikan Islam menuju pembentukan karakter. Yogyakarta: Pasca Sarjana Fakultas Ilmu Tarbiyah \& Keguruan (FITK) Universitas Islam Negeri (UIN) Sunan Kalijaga.

Maragustam, M. (2015). Paradigma revolusi mental dalam pembentukan karakter bangsa berbasis sinergitas islam dan filsafat pendidikan. Jurnal Pendidikan Agama Islam, 12(2), 161175. DOI: https://doi.org/10.14421/jpai.2015.122-03.

Munastiwi, E. (2015). Approaches in the implementation of character education (85-90). Dalam Proceedings of the 1st International Conference on Character Education. International Conference on Character Education and ST AI Sultan Abdu Hahman. Retrieved from http://digilib.uin-suka.ac.id/id/eprint/30104.

Najib, A \& Achadiyah, B. N. (2012). Pengaruh pendidikan karakter terhadap prestasi belajar siswa. Jurnal Ekonomi dan Pendidikan 9(1), 102-109. DOI: - 
https:// doi.org/10.21831/jep.v9i1.41 48.

Purwaningsih, E. (2010). Keluarga dalam mewujudkan pendidikan nilai sebagai upaya mengatasi degradasi nilai moral. Jurnal Pendidikan Sosiologi dan Humaniora, 1(1),43-55. DOI: http://dx.doi.org/10.26418/j-psh.v1i1.379.

Shabrina, S. (2020). Memperkuat kesadaran bela negara di tengah pandemi COVID19. SSRN Scholarly Paper. ID 3576300. Rochester, NY: Social Science Research Network. Retrieved from https:// papers.ssrn.com/sol3/paper s.cfm?abstract_id=3576300.

Subarto. (2020). Momentum keluarga mengembangkan kemampuan belajar peserta didik di tengah wabah pandemi Covid-19. 'ADALAH: Buletin Hukum dan Keadilan, 4(1), 13-18. DOI: 10.15408/adalah.v4i1.15383
Surat Edaran Menteri Pendidikan dan Kebudayaan Nomor 4 Tahun 2020 tentang Pelaksanaan Pendidikan dalam Masa Darurat Covid-19.

Wulandari, Y. \& Kristiawan, M. (2017). Strategi Sekolah dalam penguatan pendidikan karakter bagi siswa dengan memaksimalkan peran orang tua. JMKSP (Jurnal Manajemen, Kepemimpinan, dan Supervisi Pendidikan), 2(2), 290-303. DOI: http://dx.doi.org/10.31851/jmksp.v2i2.1477.

Yazid, S. \& Lie, L.D.J. (2020). Dampak pandemi terhadap mobilitas manusia di Asia Tenggara. Jurnal Ilmiah Hubungan Internasional, 16(1), 75-83. DOI: https://doi.org/10.26593/jihi.v0i0.38 62.75-83. 